\title{
Pseudoalteromonas peptidolytica sp. nov., a novel marine mussel-thread-degrading bacterium isolated from the Sea of Japan
}

\author{
Kasthuri Venkateswarant and Nobuhiko Dohmoto
}

Nippon Suisan Kaisha Ltd Central Research Laboratory, Hachioji City, Tokyo 192, Japan

Author for correspondence: Kasthuri Venkateswaran. Tel: +1 818393 1481. Fax: +1 8183934176. e-mail:kjvenkat@jpl.nasa.gov

\begin{abstract}
A new bacterial species belonging to the genus Pseudoalteromonas is described on the basis of phenotypic characterization, and sequence analysis of its 165 rRNA-coding and gyrase B (gyrB) genes. Ten strains, isolated from sea water of Yamato Island, Sea of Japan, were Gram-negative, yellow, motile, polarly flagellated, aerobic, rod-shaped eubacteria and had a G+C content of $42 \mathrm{~mol} \%$. Analysis of the $16 \mathrm{~S}$ rDNA sequence revealed a clear affiliation between these strains and members of the $\gamma$-Proteobacteria. High similarity values were found with members of the genus Pseudoalteromonas and this was supported by fatty acid profiles. The $16 \mathrm{~S}$ rDNA sequence similarity between strain F12-50-A1 ${ }^{\top}$ and Pseudoalteromonas piscicida was very high (99.1\%). However, molecular characterizations employing small subunit $16 \mathrm{~S}$ rDNA sequences were at the limits of resolution for the differentiation of species in this genus. As a result, DNA-DNA hybridization and sequence analyses of a more rapidly evolving gyrB gene were performed. Our assertion that this strain represents a distinct bacterial species within the genus Pseudoalteromonas was supported by both of these molecular analyses. Species-specific PCR probes were designed for the gyrB gene and used for the rapid screening of F12-50-A1'-like strains, thereby confirming the species. As these strains cleave complex protein compounds of the Mytilus edulis foot by secreting proteases, the name Pseudoalteromonas peptidolytica sp. nov. is proposed, with strain F12-50-A1' ( = MBICC F1250A1') as the type strain.
\end{abstract}

Keywords: Pseudoalteromonas peptidolytica, phylogeny, marine mussel thread, gyrB, $16 \mathrm{~S}$ rDNA

\section{INTRODUCTION}

Marine biofouling due to sedentary animals poses serious problems by increasing fluid frictional resistance of ship hulls and in pipelines, clogging of fishing nets and corrosion (Costerton et al., 1987). Previous work has shown that the permanent adhesive of Mytilus edulis is a protein containing large amounts of hydroxyproline $(13 \%)$ and 3,4-dihydroxyphenylalanine (Dopa, $11 \%$ ). Laboratory experiments have shown that treatment of the protein with clostridial

† Present address: Jet Propulsion Laboratory, NASA M/S 89-5, Planetary Protection Technologies, 4800 Oak Grove Dr., Pasadena, CA 91109, USA.

Abbreviation: Dopa, 3,4-dihydroxyphenyl-alanine.

The GenBank/EMBL/DDBJ accession numbers for the sequences reported in this paper are given in Table 3 . collagenase reduces the molecular mass by $10 \%$. Although trypsin treatment extensively degraded this polyphenolic protein, the major tryptic peptide contains 10-amino-acid (Ala-Lys-Pro-Ser-Tyr-Hyp-HypThr-Dopa-Lys) repeats. This non-degradable peptide sequence was reported to be repeated as often as 75 times in the polyphenolic protein of M. edulis (Waite, 1983). Isolation, purification and characterization of extracellular products of a novel Pseudoalteromonas strain $\mathrm{F} 12-50-\mathrm{A} 1^{\mathrm{T}}$ that are responsible for the degradation of polyphenolic protein are reported elsewhere (N. Dohmoto \& K. Venkateswaran, data not shown).

Despite the applied microbiological relevance and diversity of function embodied by the Pseudoalteromonas group, the phylogenetic breadth and organization of this group remains incompletely addressed (Baumann et al., 1984; Gauthier et al., 
1995). Introduced as Pseudomonas (Buck et al., 1963), the genus has undergone several name changes. In 1972, four species were assigned to the genus Alteromonas and since then, the genus Alteromonas has been used as a refuge for Gram-negative, heterotrophic, aerobic bacteria with a single polar flagellum which is typical of Pseudomonas members except for the low $\mathrm{G}+\mathrm{C}$ content $(38-50 \mathrm{~mol} \%)$. However, with recent improvements in the applicability of molecular approaches for microbial phylogeny, efforts are underway to clarify the phylogenetic organization of this genus. One result has been the reassessment of the distinctions between the genera Alteromonas, Pseudoalteromonas, Shewanella and Moritella (Gauthier et al., 1995). Gauthier et al. (1995) described 13 species in the genus Pseudoalteromonas. To this day, the Pseudoalteromonas group remains, almost by default, the phenotypic resting place for a growing conglomerate of non-fermentative aerobes associated with marine habitats. The phenotypic boundaries of and within this group remain ill-defined for lack of a diagnostically informative pattern of phenotypic characteristics. Furthermore, a number of novel species and Candidatus have been recently introduced including an antifouling-compound-producing Pseudoalteromonas tunicata (Holmstrom et al., 1998), a saprophytic Pseudoalteromonas bacteriolytica (Sawabe et al., 1998) and two psychrophilic species, Pseudoalteromonas antarctica (Bozal et al., 1997) and Pseudoalteromonas prydzensis (Bowman, 1998).

While the gene sequence of the small subunit of the $16 \mathrm{~S}$ rRNA molecule is accepted for the definition of phylogenetic relationships between organisms (Woese, 1987), this molecule at times lacks the specificity required for the differentiation of close relatives (Fox et al., 1992; Venkateswaran et al., 1998, 1999; Yamada et al., 1999). Nine of 17 well-described species of the genus Pseudoalteromonas showed 16S rDNA sequence similarities of $>98 \%$. To circumvent this limitation, the more rapidly evolving gyrB gene (Edgell \& Doolittle, 1997) has been used as a high-resolution molecular identification marker for distinguishing strains of Vibrio (Venkateswaran et al., 1998), the Bacillus cereus group (Yamada et al., 1999), Acinetobacter (Yamamoto et al., 1999), Pseudomonas (Yamamoto \& Harayama, 1995, 1996), Shewanella (Venkateswaran et al., 1999) and now Pseudoalteromonas.

\section{METHODS}

Bacterial strains and growth conditions. Micro-organisms included in this study were isolated from the waters of the Sea of Japan using the $R / V$ Sohgen Maru. Other strains were purchased from various culture collections. The isolation of marine mussel-thread-degrading bacteria was carried out as described by Dohmoto et al. (1993). For routine cultivation, cells were grown aerobically in marine broth (Difco) at $25^{\circ} \mathrm{C}$.

Preparation and degradation of mussel thread. Mussel thread was prepared by following the procedures of
Dohmoto et al. (1993). Briefly, mussel threads were removed from the bivalve and, after repeated washing and drying, threads were treated with ethyl acetate and ethanol before rinsing with distilled water. Filter-dried mussel thread was used as sole carbon substrate $(0.5 \%, \mathrm{w} / \mathrm{v})$ throughout the period of the study. The degradation potential was calculated after appropriate incubation conditions (Dohmoto et al., 1993) in terms of the dry weight reduction from the initial weight of the added mussel thread. Specific activity was measured by the ninhydrin method (Sarath et al., 1989).

Phenotypic characterization. Routine biochemical tests were carried out according to established procedures (Baumann et al., 1984). The ability to grow at an $\mathrm{NaCl}$ concentration of $1-10 \%$ was determined in $1 \%(\mathrm{w} / \mathrm{v})$ sterile tryptone water supplemented with the appropriate $\mathrm{NaCl}$ concentration, and the ability to grow without $\mathrm{NaCl}$ was determined in $1 \%$ tryptone water. Sugars and amino acids were tested on a minimal medium at a concentration of $1 \%$ as described elsewhere (Baumann et al., 1984). Additional phenotypic characteristics were determined by the BIOLOG microbial identification system. For the determination of cell shape and size and the detection of flagella, cells were negatively stained with osmium chloride according to the methods of Cole \& Popkin (1981) and observed with an H-600 Hitachi transmission electron microscope.

Fatty acid analysis. Cells were cultivated overnight in marine broth (Difco) at $30{ }^{\circ} \mathrm{C}$ with vigorous shaking. Cellular fatty acids were extracted from lyophilized cells, methylated and analysed by GC (Ringelberg et al., 1994). GC conditions and verification of peaks were as described elsewhere (Ringelberg et al., 1994).

\section{Molecular characterization}

(i) DNA extraction and DNA-DNA hybridization. Purified genomic DNA (Johnson, 1981) from liquid-grown cultures was used as the template for PCR amplification unless otherwise specified. PCR assays were performed in a DNA Thermal Cycler (Perkin Elmer). The $\mathrm{G}+\mathrm{C}$ content of the DNA was determined by HPLC as described by Mesbah et al. (1989). DNA-DNA hybridization was carried out as described by Huß et al. (1983) and Escara \& Hutton (1980).

(ii) 165 rDNA. Universal eubacterial primers (Bact 11 and 1492; Escherichia coli numbering) were used to amplify the $1.5 \mathrm{~kb}$ PCR fragment according to the protocols established by Ruimy et al. (1994). Amplicons thus generated were purified and sequenced as described below.

(iii) gyrB gene. Primers (UP-1 and UP-2r) within the known DNA sequence (Yamamoto \& Harayama, 1995) were added to the PCR mixture at a concentration of $1 \mu \mathrm{M}$ and the solution was subjected to 30 cycles of PCR (Venkateswaran et al., 1998). PCR-amplified $1.2 \mathrm{~kb} g y r B$ products were sequenced directly following purification on Qiagen columns. The PCR-amplified products were checked by agarose gel electrophoresis (Venkateswaran et al., 1998). Suitable molecular size markers were included in each gel.

(iv) Sequencing. The identity of a given PCR product was verified by sequencing using the dideoxy chain termination method with a Sequenase DNA sequencing kit (United States Biochemical) and with an ABI 373A automatic sequencer as recommended by the manufacturer (Perkin Elmer).

(v) Phylogenetic analysis and sequence alignment. The phylogenetic relationships of organisms covered in this study were 
determined by comparison of individual 16S rDNA sequences with the sequences deposited in the ribosomal database. $g y r B$ sequences were compared with ca. 500 other gyr $B$ sequences in the database maintained by our laboratory and S. Harayama (Marine Biotechnology Institute, Kamaishi, Iwate, Japan). Evolutionary trees were constructed with the PAUP (Swofford, 1990), PHYLIP (Felsenstein, 1990) and ARB program packages (Strunk \& Ludwig, 1995). Nucleotide sequence accession numbers are given in Table 3 .

(vi) Pseudoalteromonas peptidolytica-specific primers. Oligonucleotide primers (PP-1, forward primer, 5' ACG ACG TCA AGT CAT CAT GG; PP-2r, reverse primer, 5' GTA AGC GAA TCA CTT AAA GT) based on the gyrB gene sequence of the strain $\mathrm{F} 12-50-\mathrm{A} 1^{\mathrm{T}}$ were synthesized (Beckman) according to manufacturer's instructions. These primers were able to amplify a $205 \mathrm{bp}$ fragment. When whole bacterial cells were used as templates for PCR in the absence of a DNA extraction step, freshly grown cells from agar plates or cells from liquid culture that had been centrifuged and washed in PBS $[0 \cdot 1 \mathrm{M}, \mathrm{pH} 7 \cdot 5$, containing $2 \%(\mathrm{w} / \mathrm{v}) \mathrm{NaCl}$ ] were used. In some experiments, DNA was purified and used as a template. PCR assays were performed in a DNA Thermal Cycler (Perkin Elmer). PCR amplification of a $P$. peptidolytica-specific 205 bp fragment was performed by using 30 cycles, each consisting of $1 \mathrm{~min}$ at $94{ }^{\circ} \mathrm{C}, 1.5 \mathrm{~min}$ at $58^{\circ} \mathrm{C}, 2.5 \mathrm{~min}$ at $72^{\circ} \mathrm{C}$ and a final extension step at $72{ }^{\circ} \mathrm{C}$ for $7 \mathrm{~min}$. Following DNA amplification, the 205 bp amplicon was analysed by submarine gel electrophoresis, stained and visualized under UV illumination. Suitable molecular size markers were included in each gel.

\section{RESULTS}

\section{Degradation of marine mussel thread and synthetic decapeptide}

Of 1000 strains screened, only ten strains showed $35 \%$ degradation of mussel thread (Dohmoto et al., 1993). Strain F12-50-A ${ }^{\mathrm{T}}$ exhibited a specific activity 2295 units $\mathrm{mg}^{-1}$ against the marine mussel thread and this accounted for a degradation of $65 \%$ in terms of dry weight reduction. Similarly, the crude extracellular products of strain $\mathrm{F} 12-50-\mathrm{A} 1^{\mathrm{T}}$ showed high marine mussel thread degradation (50-70\%).

Further characterization of ten strains that showed marine mussel thread degrading ability was carried out. Phenotypic characterization (ten strains), fatty acid methyl ester analysis (three strains) and molecular analysis including 16S rDNA, gyr $B$ sequences and DNA-DNA hybridization (one strain) were performed using various sets of strains. A species-specific primer based on the $\operatorname{gyr} B$ gene of strain $\mathrm{F} 12-50-\mathrm{A} 1^{\mathrm{T}}$ was designed and the identity of the species was checked for all ten strains.

\section{Morphological and physiological characteristics}

Strain $\mathrm{F} 12-50-\mathrm{A} 1^{\mathrm{T}}$ and the other nine strains were Gram-negative, rod-shaped, non-spore-forming organisms. They grew well at $35^{\circ} \mathrm{C}$ in marine broth. Cells are $2-3 \mu \mathrm{m}$ in length and $0 \cdot 7-0.8 \mu \mathrm{m}$ in diameter,

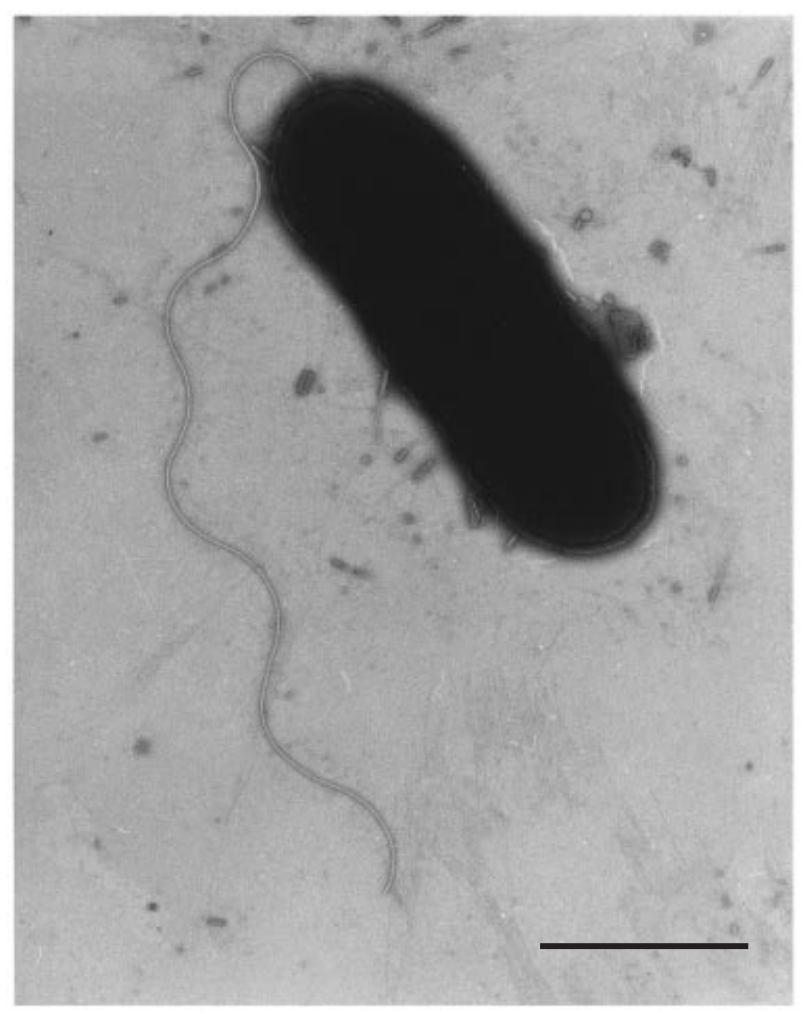

Fig. 1. Transmission electron micrograph of Pseudoalteromonas peptidolytica showing its morphology and flagellar position. Bar, $1 \mu \mathrm{m}$.

and are motile by means of a single unsheathed polar flagellum (Fig. 1). On marine agar incubated at $35^{\circ} \mathrm{C}$, young colonies are yellow and circular, with a diameter of 1-2 mm, smooth and convex with regular edges. Biochemical characterization of ten strains of these marine mussel-thread-degrading bacteria is presented in Table 1. Strains were positive for cytochrome oxidase, catalase, gelatinase, lipase, amylase and alginase and negative for the production of arginine dihydrolase and decarboxylases of lysine and ornithine. They did not show denitrification. They were unable to ferment glucose and hydrogen sulfide was not produced from thiosulfate. Indole and ketoine were not produced. The carbon substrate profile of $\mathrm{F} 12-50-\mathrm{A} 1^{\mathrm{T}}$ and the nine other strains, as measured by the BIOLOG system, showed an identification match for Pseudoalteromonas. Phenotypically, these strains resembled Pseudoalteromonas luteoviolacea.

\section{Optimum growth conditions}

These strains grew at $15-37{ }^{\circ} \mathrm{C}$ (with optimum growth at $30-35^{\circ} \mathrm{C}$ ) and at $\mathrm{pH}$ 6-10 (optimum 6-7). No growth was seen in the absence of sodium ions. As these strains were isolated from the pelagic waters of the Sea of Japan, they are halophilic and grew at $\mathrm{NaCl}$ concentrations of $1-10 \%$, with a good yield at $6 \%$. 
Table 1. Biochemical characteristics of pigmented species of Pseudoalteromonas

Strains: $1, P$. peptidolytica $(n=10) ; 2, P$. aurantia ATCC $33046^{\mathrm{T}} ; 3, P$. citrea NCIMB $1889^{\mathrm{T}} ; 4$, P. luteoviolacea ATCC $33492^{\mathrm{T}} ; 5, P$. piscicida ATCC $15057^{\mathrm{T}} ; 6$, P. rubra ATCC $29570^{\mathrm{T}} ; 7, P$. tunicata CCUG $26757^{\mathrm{T}}$. All strains are straight rods; grow at $25^{\circ} \mathrm{C}$ and $1-3 \% \mathrm{NaCl}$; produce oxidase and gelatinase; utilize D-glucose and $\mathrm{N}$-acetylglucosamine; do not denitrify; are nonluminescent; do not produce $\beta$-galactosidase, arginine dihydrolase or lysine and ornithine decarboxylases; do not utilize D-galactose, lactose, sucrose, salicin, D-mannitol, glycerol, citrate, DL-lactate, $\gamma$-aminobutyrate, sarcosine, putrescine, $\alpha$-ketoglutarate, D-sorbitol, DL-malate, acetate, $m$-hydroxybenzoate or methanol as sole carbon source.

\begin{tabular}{|c|c|c|c|c|c|c|c|}
\hline Characteristic & $1 *$ & 2 & 3 & 4 & 5 & 6 & 7 \\
\hline \multicolumn{8}{|l|}{ Growth at temperature: } \\
\hline $4{ }^{\circ} \mathrm{C}$ & 0 & + & - & - & - & - & + \\
\hline $35^{\circ} \mathrm{C}$ & 90 & - & + & + & - & + & - \\
\hline $40{ }^{\circ} \mathrm{C}$ & 90 & - & + & - & - & - & - \\
\hline Growth at $6-10 \% \mathrm{NaCl}$ & 100 & & & - & - & & \\
\hline \multicolumn{8}{|l|}{ Production of: } \\
\hline Amylase & 100 & + & + & + & - & + & \\
\hline Chitinase & 0 & - & + & - & - & - & \\
\hline Lipase & 100 & + & + & + & - & + & \\
\hline Alginase & 90 & - & - & - & - & - & \\
\hline \multicolumn{8}{|l|}{ Utilization of: } \\
\hline D-Mannose & 0 & + & + & - & + & + & + \\
\hline D-Fructose & 0 & + & + & - & - & + & - \\
\hline Maltose & 100 & - & - & + & - & + & + \\
\hline Succinate & 100 & - & - & - & - & - & \\
\hline Fumarate & 100 & - & - & - & - & - & \\
\hline Pigmentation & Yellow & Yellow & Yellow & Purple & Yellow & Red & Green \\
\hline $\mathrm{G}+\mathrm{C}$ content $(\mathrm{mol} \%)$ & $41-42$ & $38-43$ & $41-45$ & 42 & 42 & $46-48$ & $42-43$ \\
\hline
\end{tabular}

* The percentages of positive strains (out of 10) are shown.

\section{Cellular fatty acid composition}

Strain F12-50-A $1^{\mathrm{T}}$ and two other strains tested contained straight-chain, terminally branched and monounsaturated fatty acids with a composition of $24 \pm 1 \%$, $55 \pm 3 \%$ and $15 \pm 3 \%$, respectively (Table 2 ). Among those acids measured, palmitoleic $(16: 1 \omega 7 c)$ and palmitic acid (16:0) were the major fatty acids in F12$50-\mathrm{A} 1^{\mathrm{T}}$. Fatty acid methyl ester analysis of one of the closely related species, Pseudoalteromonas piscicida, showed similar profiles. Our results are in agreement with fatty acid methyl ester profiles for Pseudoalteromonas antarctica (Bozal et al., 1997), P. tunicata (Holmstrom et al., 1998) and seven other type strains of Pseudoalteromonas species (Svetashev et al., 1995). Because of the similar fatty acid composition, fatty acid methyl ester profiles could not differentiate between the Pseudoalteromonas species.

\section{Molecular phylogenetic analysis}

The marine mussel-thread-degrading strains isolated during this study closely resembled $P$. luteoviolacea by conventional phenotypic characterization and fatty acid methyl ester profiles (Svetashev et al., 1995). However, these strains were the only pseudoalteromonads showing degradation of marine mussel thread. To confirm the species identity, the molecular phylogeny of this strain was analysed.

(i) $16 \mathrm{~S}$ rDNA sequence analysis. The $16 \mathrm{~S}$ rDNA sequences of all known $\gamma$-Proteobacteria were compared with that of F12-50-A ${ }^{\mathrm{T}}$. All phylogenetic analyses of its $16 \mathrm{~S}$ rDNA sequence unambiguously demonstrated that F12-50-A1 ${ }^{\mathrm{T}}$ belonged to the phylum $\gamma$-Proteobacteria. Their phylogenetic relationships were then analysed, and this study was repeated with several different subdomains of the $16 \mathrm{~S}$ rDNA sequence and bootstrapping analysis was performed to avoid sampling artifacts. The resulting analysis indicated that F12-50-A $1^{\mathrm{T}}$ shared a close phylogenetic relationship with the species of Pseudoalteromonas, Alteromonas, Shewanella and Vibrio. Neighbour-joining, parsimony and maximum-likelihood analyses were then undertaken on this subset of bacteria, using several subdomains of the $16 \mathrm{~S}$ rDNA. In all analyses, F12-50-A1 ${ }^{\mathrm{T}}$ was most closely associated with members of the genus Pseudoalteromonas.

The similarities in the 16S rDNA nucleotide sequences between $\mathrm{F} 12-50-\mathrm{A} 1^{\mathrm{T}}$ and 17 Pseudoalteromonas species were between 89 and $99 \%$ (Table 3). A variation of only $1 \%$ was found between $\mathrm{F} 12-50-\mathrm{A} 1^{\mathrm{T}}$ and $P$. piscicida, and $3 \%$ between $\mathrm{F} 12-50-\mathrm{A} 1^{\mathrm{T}}$ and 
Table 2. Fatty acid composition of $P$. peptidolytica and related species

\begin{tabular}{|c|c|c|c|c|}
\hline \multirow[t]{3}{*}{ Fatty acid } & \multicolumn{4}{|c|}{ Fatty acid methyl esters (\%) produced in strains: } \\
\hline & \multicolumn{3}{|c|}{$P \cdot$ peptidolytica } & \multirow{2}{*}{$\begin{array}{c}\text { P. piscicida } \\
\text { ATCC } 15057^{\mathrm{T}}\end{array}$} \\
\hline & $\mathrm{F} 12-50-\mathrm{A} 1^{\mathrm{T}}$ & F5-100-B2 & F5-100-C1 & \\
\hline $10: 0$ & 0.93 & $0 \cdot 71$ & $1 \cdot 02$ & $0 \cdot 68$ \\
\hline $10: 03 \mathrm{OH}$ & $2 \cdot 16$ & 1.91 & 1.94 & $1 \cdot 62$ \\
\hline Unknown 11.798 & $1 \cdot 64$ & $1 \cdot 72$ & $1 \cdot 64$ & $1 \cdot 28$ \\
\hline Unknown $12 \cdot 486$ & $0 \cdot 09$ & & & $0 \cdot 12$ \\
\hline $11: 0$ & & $0 \cdot 10$ & & \\
\hline $11: 03 \mathrm{OH}$ & & $0 \cdot 61$ & $0 \cdot 77$ & \\
\hline $11: 0$ iso $3 \mathrm{OH}$ & $0 \cdot 12$ & & & \\
\hline $12: 0$ & $1 \cdot 85$ & $2 \cdot 12$ & 1.91 & $1 \cdot 86$ \\
\hline $12: 0$ iso $3 \mathrm{OH}$ & $0 \cdot 22$ & $0 \cdot 44$ & $0 \cdot 18$ & $0 \cdot 16$ \\
\hline $12: 13 \mathrm{OH}$ & $0 \cdot 11$ & $0 \cdot 16$ & $0 \cdot 20$ & 0.09 \\
\hline $12: 03 \mathrm{OH}$ & $6 \cdot 14$ & $5 \cdot 96$ & $5 \cdot 01$ & $6 \cdot 35$ \\
\hline $13: 1$ & $0 \cdot 14$ & & & \\
\hline $14: 0$ & $3 \cdot 11$ & $2 \cdot 91$ & $2 \cdot 01$ & $4 \cdot 35$ \\
\hline $15: 1 \omega 8 c$ & $0 \cdot 35$ & $0 \cdot 69$ & 0.93 & \\
\hline $15: 0$ iso & & & & \\
\hline $15: 0$ & & $0 \cdot 87$ & $0 \cdot 90$ & \\
\hline $16: 0$ iso & $0 \cdot 12$ & $0 \cdot 21$ & & $0 \cdot 15$ \\
\hline $16: 1 \omega 9 c$ & $0 \cdot 87$ & $1 \cdot 21$ & $1 \cdot 34$ & $1 \cdot 53$ \\
\hline $16: 0$ & $17 \cdot 46$ & $16 \cdot 68$ & $17 \cdot 21$ & $20 \cdot 65$ \\
\hline $17: 1 \omega 8 c$ & $0 \cdot 19$ & $2 \cdot 11$ & 1.92 & \\
\hline $17: 0$ & & $0 \cdot 67$ & $0 \cdot 61$ & \\
\hline $18: 1 \omega 7 t$ & $3 \cdot 03$ & & & $5 \cdot 81$ \\
\hline $18: 1 \omega 9 c$ & $0 \cdot 39$ & $0 \cdot 63$ & $0 \cdot 55$ & $0 \cdot 50$ \\
\hline $18: 0$ & 0.93 & $1 \cdot 18$ & $1 \cdot 21$ & $1 \cdot 18$ \\
\hline
\end{tabular}

Pseudoalteromonas rubra. A very high variation (11\%) was noticed between F12-50-A1 ${ }^{\mathrm{T}}$ and $P$. bacteriolytica. Such a high degree of variation within a well-described genus is uncommon. This value is somewhat close to the variation seen between $\mathrm{F} 12-50-\mathrm{A} 1^{\mathrm{T}}$ and Alteromonas macleodii $(12 \cdot 5 \%)$.

A phylogenetic tree based on $16 \mathrm{~S}$ rDNA sequences is shown in Fig. 2. The branching order of this tree shows two distinct clusters in which $P$. bacteriolytica evolved earlier than the rest with a distinct stock adjacent to $A$. macleodii. Non-pigmented strains exhibited five subclusters and pigmented strains showed four subclusters: two individual clades for $P$. prydzensis and $P$. tunicata; one clade composed of Pseudoalteromonas citrea and Pseudoalteromonas aurantia; and the other clade composed of $P$. luteoviolacea, $P$. piscicida, $P$. rubra and strain $\mathrm{F} 12-50-\mathrm{A} 1^{\mathrm{T}}$.

(ii) gyrB sequence analysis. The $1.2 \mathrm{~kb}$ nucleotide sequences of the $g y r B$ gene were determined for A. macleodii, 11 available well-described Pseudoalteromonas species and $\mathrm{F} 12-50-\mathrm{A} 1^{\mathrm{T}}$. Although $16 \mathrm{~S}$ rDNA sequences had $99 \%$ similarity between phenotypically distinct $\mathrm{F} 12-50-\mathrm{A} 1^{\mathrm{T}}$ and $P$. piscicida, the $12 \%$ variation seen in $\operatorname{gyr} B$ nucleotide sequences between them supports their species differentiation.
The similarities in $g y r B$ nucleotide sequences with F12$50-\mathrm{A} 1^{\mathrm{T}}$ and other species were between 75 and $88 \%$ (Table 3). It is obvious that $\mathrm{F} 12-50-\mathrm{A} 1^{\mathrm{T}}$ had greater similarity with pigmented Pseudoalteromonas $(82-88 \%)$ than with non-pigmented species $(78-80 \%)$. A very high variation $(21 \%)$ was observed between F12-50-A1 ${ }^{\mathrm{T}}$ and Pseudoalteromonas haloplanktis subsp. haloplanktis. This value is somewhat close to the variation seen between $\mathrm{F} 12-50-\mathrm{A} 1^{\mathrm{T}}$ and $A$. macleodii $(25 \%)$. Amino acid translation of $g y r B$ nucleotide sequences of $\mathrm{F} 12-50-\mathrm{A} 1^{\mathrm{T}}$ exhibited similarities of $92-96 \%$ and $88-90 \%$ with pigmented and non-pigmented Pseudoalteromonas species, respectively.

The relative phylogenetic positions occupied by each of the Pseudoalteromonas type strains, based on $g y r B$ nucleotide sequences, are shown in Fig. 3. An unrooted tree was generated by the maximum-likelihood method. The branching order of the gyrB-based tree resembles that of a similar tree based on $16 \mathrm{~S}$ rDNA nucleotide sequences. The seven non-pigmented strains formed a distinct cluster. The other five pigmented strains, $P$. aurantia, $P$. citrea, $P$. luteoviolacea, $P$. piscicida and strain F12-50-A $1^{\mathrm{T}}$, clustered into a distinct group of perfect integrity with regard to 
Table 3. Percentage similarities of $\mathrm{F} 12-50-\mathrm{A} 1^{\top}$ strain sequences with other Pseudoalteromonas species and accession numbers of various nucleotide sequences

\begin{tabular}{|c|c|c|c|c|c|c|c|}
\hline \multirow[t]{3}{*}{ Bacterial strain } & \multirow[t]{3}{*}{ Strain no. } & \multirow[t]{3}{*}{ Place of isolation } & \multicolumn{3}{|c|}{ Sequence similarities $(\%)$ : } & \multirow{2}{*}{\multicolumn{2}{|c|}{$\begin{array}{l}\text { Accession no. for } \\
\text { the sequences of: }\end{array}$}} \\
\hline & & & \multirow{2}{*}{$\begin{array}{c}\text { 16S } \\
\text { rDNA }\end{array}$} & \multicolumn{2}{|c|}{$\operatorname{gyr} B$} & & \\
\hline & & & & $\begin{array}{l}\text { Nucleic } \\
\text { acid }\end{array}$ & $\begin{array}{l}\text { Amino } \\
\text { acid }\end{array}$ & 16S rDNA* & $\operatorname{gyr} B \dagger$ \\
\hline A. macleodii & NCIMB $1963^{\mathrm{T}}$ & Sea water & $87 \cdot 7$ & $75 \cdot 3$ & $82 \cdot 3$ & $\mathrm{X} 82145$ & AF007272 \\
\hline P. antarctica & CECT $4664^{\mathrm{T}}$ & Sea water, Antarctica & $93 \cdot 7$ & NT & NT & X98336 & \\
\hline P. atlantica & NCIMB $301^{\mathrm{T}}$ & Seaweed, Canada & $94 \cdot 7$ & $79 \cdot 8$ & 88.6 & X82134 & AF007274 \\
\hline P. aurantia & ATCC $33046^{\mathrm{T}}$ & Sea water & $93 \cdot 5$ & 87.7 & $96 \cdot 2$ & X82135 & AF007275 \\
\hline P. bacteriolytica & IAM $14594^{\mathrm{T}}$ & Red spot disease, Laminaria & $89 \cdot 0$ & NT & NT & D89929 & \\
\hline P. carrageenovora & NCIMB $302^{\mathrm{T}}$ & Sea water, Canada & $94 \cdot 6$ & $80 \cdot 0$ & $90 \cdot 3$ & X82136 & AF007276 \\
\hline P. citrea & NCIMB $1889^{\mathrm{T}}$ & Sea water & $93 \cdot 5$ & $82 \cdot 1$ & $92 \cdot 2$ & X82137 & AF007277 \\
\hline P. denitrificans & ATCC $43337^{\mathrm{T}}$ & Sea water, Norway & $92 \cdot 3$ & NT & NT & X82138 & \\
\hline P. espejiana & NCIMB $2127^{\mathrm{T}}$ & Sea water, California, USA & $94 \cdot 9$ & $79 \cdot 3$ & 88.4 & X82143 & AF007278 \\
\hline $\begin{array}{l}\text { P. haloplanktis } \\
\text { subsp. haloplanktis }\end{array}$ & NCIMB $2084^{\mathrm{T}}$ & Sea water & $93 \cdot 7$ & $79 \cdot 1$ & $88 \cdot 9$ & X67024 & AF007279 \\
\hline P. luteoviolacea & ATCC $33492^{\mathrm{T}}$ & Sea water, France & $96 \cdot 4$ & $82 \cdot 8$ & $94 \cdot 7$ & X82144 & AF007280 \\
\hline P. nigrifaciens & ATCC $19375^{\mathrm{T}}$ & Butter & $94 \cdot 4$ & $78 \cdot 2$ & 87.7 & X82146 & AF007281 \\
\hline P. peptidolytica & $\mathrm{F} 12-50-\mathrm{A} 1^{\mathrm{T}}$ & Sea water, Japan & & & & AF007286† & AF007285 \\
\hline P. piscicida & ATCC $15057^{\mathrm{T}}$ & $\begin{array}{l}\text { Red Tide sea water, Florida, } \\
\text { USA }\end{array}$ & $99 \cdot 1$ & $87 \cdot 9$ & $97 \cdot 1$ & X82215 & AF139115 \\
\hline P. prydzensis & ACAM $620^{\mathrm{T}}$ & $\begin{array}{l}\text { Sea ice, Prdyz Bay, } \\
\text { Antarctica }\end{array}$ & $92 \cdot 7$ & NT & NT & U85855 & \\
\hline P. rubra & ATCC $29570^{\mathrm{T}}$ & Sea water, France & $97 \cdot 0$ & NT & NT & X82147 & \\
\hline $\begin{array}{l}\text { P. haloplanktis subsp. } \\
\text { tetraodonis }\end{array}$ & NCIMB $13177^{\mathrm{T}}$ & Skin slime of pufferfish & $91 \cdot 5$ & NT & NT & X82139 & AF007283 \\
\hline P. tunicata & CCUG $26757^{\mathrm{T}}$ & Tunicates, Austr: & $95 \cdot 2$ & $79 \cdot 8$ & $88 \cdot 4$ & Z25522 & \\
\hline P. undina & NCIMB $2128^{\mathrm{T}}$ & Sea water, California, USA & $94 \cdot 1$ & $79 \cdot 5$ & $89 \cdot 6$ & X82140 & AF007284 \\
\hline
\end{tabular}

* Data retrieved from GenBank database for comparison.

$\dagger$ Generated for this study.

NT, Not tested.

species. The branching order of the tree based on the amino acid sequences of $\operatorname{gyr} B$ (Fig. 4) was very similar to that based on the $\operatorname{gyr} B$ nucleotide sequences. However, three distinct subclusters were noted among the non-pigmented Pseudoalteromonas species.

(iii) DNA-DNA hybridization. DNA-DNA hybridization was performed between F12-50-A $1^{\mathrm{T}}$ (Table 4), three pigmented strains $(2 \cdot 0-3 \cdot 4 \%)$, one non-pigmented Pseudoalteromonas species (P. haloplanktis subsp. haloplanktis, $1 \cdot 0 \%)$, E. coli $(0 \cdot 2 \%)$ and Bacillus subtilis $(0.8 \%)$. None of the values were above the $70 \%$ similarity that would place the strain within the same species. In particular, the similarity between $P$. peptidolytica and $P$. piscicida was only $2.0 \%$; this pair showed $99.1 \%$ similarities in their $16 \mathrm{~S}$ rDNA sequences. Similarly, $P$. aurantia and $P$. citrea showed only $10 \%$ DNA-DNA hybridization values but exhibited $99.7 \%$ similarity in their $16 \mathrm{~S}$ rDNA sequence.

(iv) Designing $P$. peptidolytica-specific PCR primers. A species-specific primer set of $20 \mathrm{bp}$ each was designed to specifically detect and differentiate $\mathrm{F} 12-50-\mathrm{A} 1^{\mathrm{T}}$ from other related species. When these primers were used to generate $205 \mathrm{bp}$ PCR products, F12-50-A $1^{\mathrm{T}}$ could be differentiated from $P$. piscicida. A total of 160 strains comprising 72 different species was screened for both the $1.2 \mathrm{~kb}$ gyr $B$ gene and $\mathrm{F} 12-50-\mathrm{A} 1^{\mathrm{T}}$-specific $205 \mathrm{bp}$ fragments. These species include members of the genera Pseudoalteromonas, Alteromonas, Vibrio, Aeromonas, Plesiomonas, Photobacterium and Halomonas. A specific band of $205 \mathrm{bp}$ was noticed only for the ten strains that degrade marine mussel thread but no other bacterial species exhibited any amplicon. However, PCR amplification using primer set UP-1 and UP-2r revealed a $1.2 \mathrm{~kb}$ gyr $B$ fragment in all strains examined, thus ascertaining the presence of the DNA gyrase B subunit. Thus, the primers developed and described here (PP-1 and PP-2r) are specific to $\mathrm{F} 12-50-\mathrm{A} 1^{\mathrm{T}}$ and the other nine marine mussel-threaddegraders and could be used to screen this species. This indirect approach saves cost and labour but confirms the specificity of the species. 


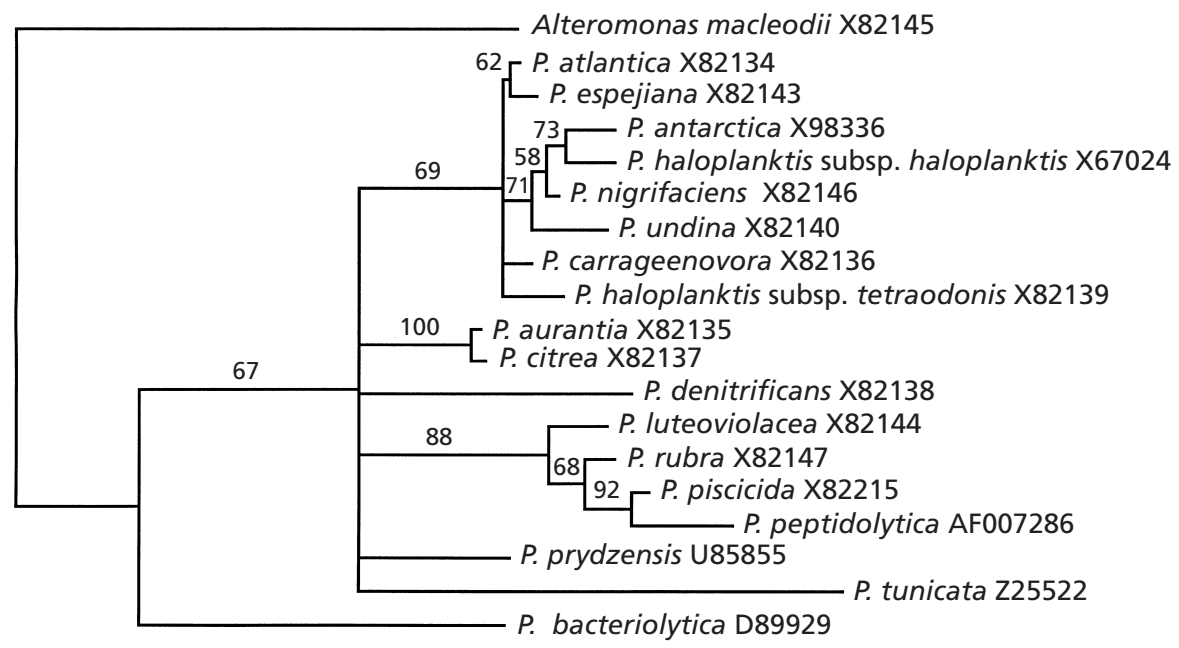

Fig. 2. Phylogenetic tree of type strains of various Pseudoalteromonas species based on $16 \mathrm{~S}$ rDNA nucleotide sequences.

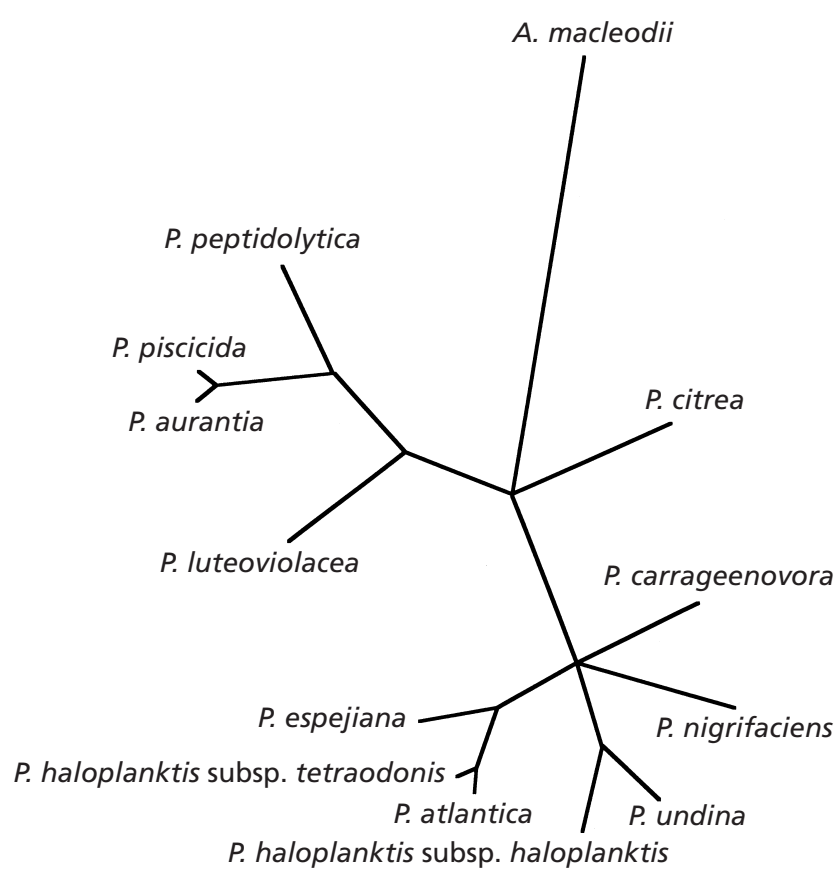

Fig. 3. Phylogenetic tree of type strains of various species of Pseudoalteromonas based on gyrB nucleotide sequences.

\section{DISCUSSION}

Phenotypic characteristics, such as positive oxidase and gelatinase reactions, the absence of glucose fermentation, a strict respiratory metabolism, an ability to grow only in higher $\mathrm{NaCl}$ concentrations, and a $\mathrm{G}+\mathrm{C}$ content of $42 \mathrm{~mol} \%$ seem to be sufficient to warrant the inclusion of $\mathrm{F} 12-50-\mathrm{A} 1^{\mathrm{T}}$ in the genus Pseudoalteromonas. Although some key characteristics could differentiate the strain $\mathrm{F} 12-50-\mathrm{Al}^{\mathrm{T}}$ and nine marine mussel-thread-degraders from other species of Pseudoalteromonas, conventional biochemical testing and fatty acid methyl ester profiles place these strains within the pigmented species of Pseudoalteromonas. Molecular methods are tacitly less susceptible to artifactual misinterpretation than culture-based approaches. It has been revealed that organisms with less than $97 \%$ similarity over the $16 \mathrm{~S}$ rRNA gene do not yield DNA reassociation values of more than $60 \%$; hence, rDNA sequence analysis may be used as a surrogate for DNA reassociation (Stackebrandt \& Goebel, 1994).

Strain $\mathrm{F} 12-50-\mathrm{A} 1^{\mathrm{T}}$ shares $>96 \%$ similarity in $16 \mathrm{~S}$ rDNA sequences with three pigmented Pseudoalteromonas species. However, phenotypic characters of $\mathrm{F} 12-50-\mathrm{A} 1^{\mathrm{T}}$ and nine other strains are different from these species. P. luteoviolacea shows a distinct purple pigmentation, and all three species do not grow at high $\mathrm{NaCl}$ concentration $(6-10 \%)$. Furthermore, F12-50-A $1^{\mathrm{T}}$ and other closely related species exhibited very low DNA-DNA similarities which suggests that this strain represents a new species. The species-specific PCR confirmed that nine of the other marine musselthread-degraders belong to the same species as F12$50-\mathrm{A} 1^{\mathrm{T}}$. In addition, $\mathrm{F} 12-50-\mathrm{A} 1^{\mathrm{T}}$ and the nine other strains of the proposed novel species secrete proteases that are not produced by any of the known Pseudoalteromonas species.

In general, Pseudoalteromonas species could not be differentiated based on the $97 \%$ 16S rDNA threshold level. Among Pseudoalteromonas species known, the percentage of nucleotide substitutions in the $16 \mathrm{~S}$ rDNA sequences varied from 0.3 to $11.0 \%$. It should be noted that some of the established phenotypically distinct species grouped together and had $<3.0 \%$ dissimilarities in their 16S rDNA nucleotide sequences. For example: $P$. antarctica, Pseudoalteromonas atlantica, Pseudoalteromonas carrageenovora, Pseudoalteromonas espejiana, P. haloplanktis subsp. haloplanktis, Pseudoalteromonas nigrifaciens, Pseudoalteromonas haloplanktis subsp. tetraodonis and 


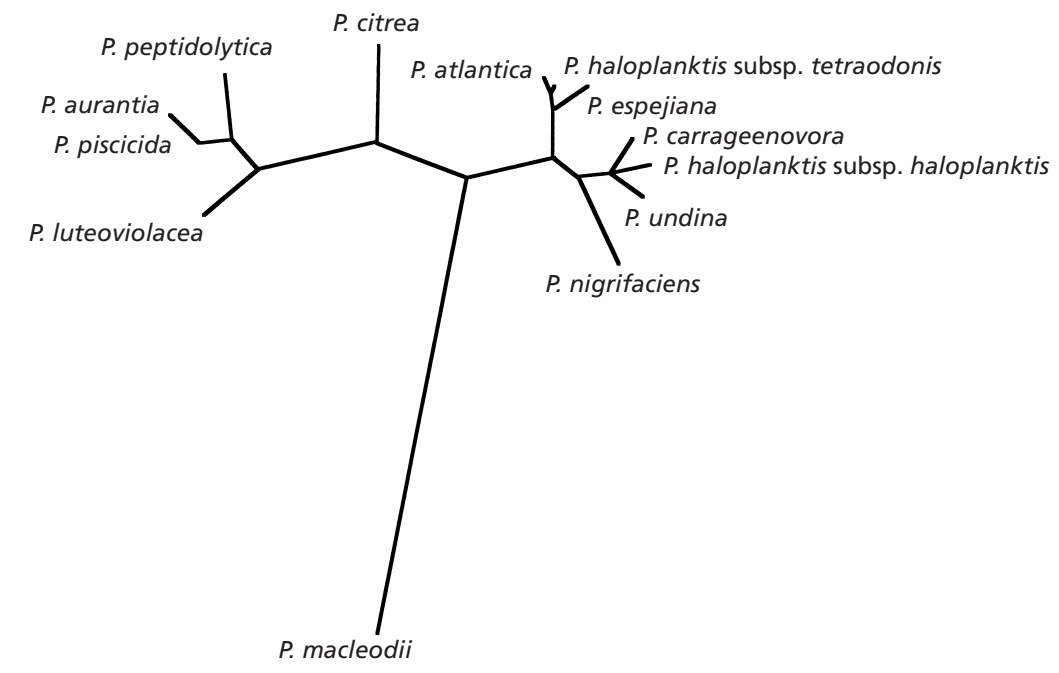

Fig. 4. Phylogenetic tree of type strains of various species of Pseudoalteromonas based on gyrB amino acid sequences.

Table 4. DNA-DNA hybridization of various Pseudoalteromonas species

Strains: 1, P. peptidolytica $\mathrm{F} 12-50-\mathrm{Al}^{\mathrm{T}} ; 2$, P. aurantia NCIMB $2033^{\mathrm{T}} ; 3$, P. citrea NCIMB $1889^{\mathrm{T}}$; 4, $P$. piscicida ATCC $15057^{\mathrm{T}}$.

\begin{tabular}{|c|c|c|c|c|c|}
\hline \multirow[t]{2}{*}{ Bacterium } & \multirow[t]{2}{*}{ Strain no. } & \multicolumn{4}{|c|}{ Similarity (\%) to labelled DNA from: } \\
\hline & & 1 & 2 & 3 & 4 \\
\hline P. peptidolytica & $\mathrm{F} 12-50-\mathrm{A} 1^{\mathrm{T}}$ & $100 \cdot 0$ & & & \\
\hline P. aurantia & NCIMB $2033^{\mathrm{T}}$ & $3 \cdot 0$ & $100 \cdot 0$ & & \\
\hline P. citrea & NCIMB $1889^{\mathrm{T}}$ & $3 \cdot 4$ & $10 \cdot 0$ & $100 \cdot 0$ & \\
\hline P. piscicida & ATCC $15057^{\mathrm{T}}$ & $2 \cdot 0$ & NT & $12 \cdot 0$ & $100 \cdot 0$ \\
\hline P. luteoviolacea & ATCC $33492^{\mathrm{T}}$ & $2 \cdot 2$ & $11 \cdot 0$ & $12 \cdot 0$ & $8 \cdot 0$ \\
\hline $\begin{array}{l}\text { P. haloplanktis subsp. } \\
\text { haloplanktis }\end{array}$ & NCIMB $2084^{\mathrm{T}}$ & $1 \cdot 0$ & $8 \cdot 0$ & $14 \cdot 0$ & $8 \cdot 0$ \\
\hline E. coli & ATCC 25922 & $0 \cdot 2$ & NT & NT & NT \\
\hline B. subtilis & ATCC 6051 & $0 \cdot 8$ & NT & NT & NT \\
\hline
\end{tabular}

NT, Not tested.

Pseudoalteromonas undina formed a group that exhibited $<2.5 \%$ dissimilarity; a second group, $P$. citrea and $P$. aurantia, showed only 5 bp substitution in their $1.5 \mathrm{~kb} 16 \mathrm{~S}$ rDNA sequences and a third group, $P$. luteoviolacea, P. piscicida, P. rubra and F12-50-A ${ }^{\mathrm{T}}$ strain, showed $<3.0 \%$ dissimilarity.

The base substitution frequency of $g y r B$ is much higher than that of the 16S rRNA gene, making it a more appropriate choice for differentiating close phylogenetic relationships (Ochman \& Wilson, 1987). Based on the comparison of $g y r B$ sequences of various genera (Yamamoto \& Harayama, 1995, 1996; Venkateswaran et al., 1998, 1999; Yamada et al., 1999), a species cutoff value of $90 \%$ was proposed (Venkateswaran et al., 1999). Even though the 16S rDNA similarities are inconclusive at $97 \%$ in some bacterial genera, when the $\operatorname{gyr} B$ criteria are applied, low similarities were noted among closely related species. In this study, the gyr B sequences of F12-50-A ${ }^{\mathrm{T}}$ and $P$. piscicida showed only $88 \%$ similarity that would confirm a species status for $\mathrm{F} 12-50-\mathrm{A} 1^{\mathrm{T}}$. This was further verified by their low DNA-DNA reassociation values.

\section{Description of Pseudoalteromonas peptidolytica sp. nov.}

Pseudoalteromonas peptidolytica (pep.ti.do.ly'ti.ca. Gr. n. peptos a class of organic compounds; Gr. adj. lytica dissolving; M.L. fem. adj. peptidolytica peptide repeats dissolving)

Cells of the type strain are rod-shaped. They are $2-3 \mu \mathrm{m}$ in length and $0.7-0.8 \mu \mathrm{m}$ in diameter. Gramnegative, aerobic, polarly flagellated bacteria. Neither endospores nor capsules formed. Colonies on marine agar medium are circular, smooth, convex with regular edges and yellow-pigmented. Sodium ions are essential for growth. Able to grow at $15-40{ }^{\circ} \mathrm{C}$ with optimum growth at $30^{\circ} \mathrm{C}$. Produces cytochrome oxidase, 
catalase, gelatinase, lipase, amylase and alginase. Aerobically utilizes maltose, succinate, fumarate, glucose and $N$-acetylglucosamine. Does not produce $\mathrm{H}_{2} \mathrm{~S}$ from thiosulfate or denitrify. Does not produce $\beta$ galactosidase, arginine dihydrolase or lysine and ornithine decarboxylases. Based on both 16S rDNA and gyr $B$ nucleotide sequences, this bacterium belongs to the $\gamma$-Proteobacteria and is a member of the genus Pseudoalteromonas. The type strain F12-50-A $1^{\mathrm{T}}$ $\left(=\right.$ MBICC F1250A $\left.1^{\mathrm{T}}\right)$ was isolated from the surface waters of the Yamato Islands, in the Sea of Japan.

\section{ACKNOWLEDGEMENTS}

We thank M. Satake and S. Harayama for valuable advice and encouragement. Our sincere thanks to M. Satomi for the DNA-DNA hybridization experiments.

\section{REFERENCES}

Baumann, P., Gauthier, M. J. \& Baumann, L. (1984). Genus Alteromonas Baumann, Baumann, Mandel and Allen, 1972, 418. In Bergey's Manual of Systematic Bacteriology, pp. 243-352. Edited by N. R. Kreig \& J. G. Holt. Baltimore: Williams \& Wilkins.

Bowman, J. (1998). Pseudoalteromonas prydzensis sp. nov., a psychrophilic, halotolerant bacterium from Antarctic sea ice. Int J Syst Bacteriol 48, 1037-1041.

Bozal, N., Tudela, E., Rossello-Mora, R., Lalucat, J. \& Guinea, J. (1997). Pseudoalteromonas antarctica sp. nov., isolated from an Antarctic coastal environment. Int J Syst Bacteriol 47, 345-351.

Buck, J. D., Meyers, S. P. \& Leifson, E. (1963). Pseudomonas (Flavobacterium) piscicida Bein comb. nov. J Bacteriol 86, 1125-1126.

Cole, R. M. \& Popkin, T. J. (1981). Electron microscopy. In Manual of Methods for General Bacteriology, pp. 34-51. Edited by P. Gerhardt, R. G. E. Murray, R. N. Costilaw, E. W. Nester, W. A. Wood, N. R. Krieg \& G. B. Phillips. Washington, DC: American Society for Microbiology.

Costerton, J. W., Cheng, K. J., Geesey, G. G., Ladd, T. I., Nickel, J. C., Dasgupta, M. \& Marrie, T. J. (1987). Bacterial biofilms in nature and disease. Annu Rev Microbiol 41, 435-464.

Dohmoto, N., Venkateswaran, K., Nose, T., Tanaka, H., Miki, W. \& Miyachi, S. (1993). Marine mussel-thread-degrading bacteria and partial purification of proteinases responsible for degradation. J Mar Biotechnol 1, 83-87.

Edgell, D. R. \& Doolittle, W. F. (1997). Archaea and the origin(s) of DNA replicon proteins. Cell 89, 995-998.

Escara, J. F. \& Hutton, J. R. (1980). Thermal stability and renaturation of DNA in dimethylsulphoxide solutions: acceleration of renaturation rate. Biopolymers 19, 1315-1327.

Felsenstein, J. (1990). PHYLIP manual version 3.3. University Herbarium, University of California, Berkeley, CA, USA.

Fox, G. E., Wisotzkey, J. D. \& Jurtshuk, P., Jr (1992). How close is close: 16S rRNA sequence identity may not be sufficient to guarantee species identity. Int J Syst Bacteriol 42, 166-170.

Gauthier, G., Gauthier, M. \& Christen, R. (1995). Phylogenetic analysis of genera Alteromonas, Shewanella, and Moritella using genes coding for small-subunit rRNA sequences and division of the genus Alteromonas into two genera, Alteromonas (emended) and Pseudoalteromonas gen. nov., and proposal of twelve new species combinations. Int $J$ Syst Bacteriol 45, 755-761.

Holmstrom, C., James, S., Neilan, B. A., White, D. C. \& Kjelleberg, S. (1998). Pseudoalteromonas tunicata sp. nov., a bacterium that produces antifouling agents. Int J Syst Bacteriol 48, 1205-1212.

Huß, V. A. R., Festl, H. \& Schleifer, K. H. (1983). Studies on the spectrophotometric determination of DNA hybridization from renaturation rates. Syst Appl Microbiol 4, 184-192.

Johnson, J. L. (1981). Genetic characterization. In Manual of Methods for General Bacteriology, pp. 34-51. Edited by P. Gerhardt, R. G. E. Murray, R. N. Costilaw, E. W. Nester, W. A. Wood, N. R. Krieg \& G. B. Phillips. Washington, DC: American Society for Microbiology.

Mesbah, M., Premachandran, U. \& Whitman, W. B. (1989). Precise measurement of the $\mathrm{G}+\mathrm{C}$ content of deoxyribonucleic acid by high-performance liquid chromatography. Int $J$ Syst Bacteriol 39, 159-167.

Ochman, H. \& Wilson, A. C. (1987). Evolution in bacteria: evidence for a universal substitution rate in cellular genomes. J Mol Evol 26, 74-86.

Ringelberg, D. B., Townsend, G. T., DeWeerd, K. A., Suflita, J. M. \& White, D. C. (1994). Detection of the anaerobic dechlorinating microorganism Desulfomonile tiedjei in environmental matrices by its signature lipopolysaccharide branched-long-chain hydroxy fatty acids. FEMS Microbiol Ecol 14, 9-18.

Ruimy, R., Breittmayer, V., ElBaze, P., Lafay, B., Boussemart, O., Gauthier, M. \& Christen, R. (1994). Phylogenic analysis and assessment of the genera Vibrio, Photobacterium, Aeromonas, and Plesiomonas deduced from small subunit rRNA sequences. Int J Syst Bacteriol 44, 416-426.

Sarath, G., De La Motte, R. S. \& Wagner, F. W. (1989). Proteolytic enzymes. In Proteases Assay Methods, pp. 25-55. Edited by R. J. Beynon \& J. S. Bonds. Oxford: IRL/Oxford University Press.

Sawabe, T., Makino, H., Tatsumi, M., Nakano, K., Tajima, K., Iqbal, M. M., Yumoto, I., Ezura, Y. \& Christen, R. (1998). Pseudoalteromonas bacteriolytica sp. nov., a marine bacterium that is the causative agent of red spot disease of Laminaria japonica. Int J Syst Bacteriol 48, 769-774.

Stackebrandt, E. \& Goebel, B. M. (1994). A place for DNA-DNA reassociation and $16 \mathrm{~S}$ rRNA sequence analysis in the present species definition in bacteriology. Int $J$ Syst Bacteriol 44, 846-849.

Strunk, O. \& Ludwig, W. (1995). ARB - a software environment for sequence data. Department of Microbiology, Technical University of Munich, Munich, Germany.

Svetashev, V. I., Vysotskii, M. V., Ivanova, E. P. \& Mikhailov, V. V. (1995). Cellular fatty acids of Alteromonas species. Syst Appl Microbiol 18, 37-43.

Swofford, D. (1990). PAUP: phylogenetic analysis using parsimony, version 3.0. Computer program distributed by the Illinois Natural History Survey, Champaign, IL, USA.

Venkateswaran, K., Dohmoto, N. \& Harayama, S. (1998). Cloning and nucleotide sequence of $g y r B$ gene of Vibrio parahaemolyticus and its application in detection of the pathogen in shrimp. Appl Environ Microbiol 64, 681-687.

Venkateswaran, K., Moser, D. P., Dollhopf, M. E. \& 10 other authors (1999). Polyphasic taxonomy of the genus Shewanella and description of Shewanella oneidensis sp. nov. Int J Syst Bacteriol 49, 705-724.

Waite, J. H. (1983). Evidence for a repeating 3,4-dihydroxy- 
phenylalanine- and hydroxyproline-containing decapeptide in the adhesive protein of the mussel, Mytilus edulis L. J Biol Chem 258, 2911-2915.

Woese, C. R. (1987). Bacterial evolution. Microbiol Rev 51, 221-271.

Yamada, S., Ohashi, E., Agata, N. \& Venkateswaran, K. (1999). Cloning and nucleotide sequences of gyr $B$ of Bacillus cereus, $B$. thuringiensis, $B$. anthracis and B. mycoides and its application in the detection B. cereus in rice. Appl Environ Microbiol 65, 1483-1490.

Yamamoto, S. \& Harayama, S. (1995). PCR amplification and direct sequencing of $g y r B$ genes with universal primers and their application to the detection and taxonomic analysis of Pseudomonas putida strains. Appl Environ Microbiol 61, 1104-1109.

Yamamoto, S. \& Harayama, S. (1996). Phylogenetic analysis of Acinetobacter strains on the nucleotide sequences of $g y r B$ genes and on the amino acid sequences of their products. Appl Environ Microbiol 46, 506-511.

Yamamoto, S., Bouvet, P. J. \& Harayama, S. (1999). Phylogenetic structures of the genus Acinetobacter based on gyrB sequences: comparison with the grouping by DNA-DNA hybridization. Int J Syst Bacteriol 49, 87-95. 